\title{
RESTORATION OF INVOLUTED ZYMOGENIC CELLS IN HYPOPHYSECTOMIZED RATS BY REPLACEMENT THERAPY ${ }^{1}$
}

\author{
BURTON L. BAKER \\ Department of Anatomy, University of Michigan \\ Medical School, Ann Arbor
}

NINE FIGURES

Following hypophysectomy of the rat, partial involution occurs in the zymogenic cells of the stomach (Baker and Abrams, '54), parotid gland (Baker and Abrams, '55), pancreas (Baker and Pliske, '57), submandibular gland (Lacassagne and Chamorro, '40; Grad and Leblond, '49), and in the intestinal cells of Paneth (Baker, Kent and Pliske, in press). Insofar as they have been studied, enzyme synthesis is suppressed in these cells, also. The question of how the hypophysis exerts its influence over zymogenic cells will be answered only when they are restored to normal in hypophysectomized rats by replacement therapy.

The purpose of this report is to present the results of experiments in which somatotropin, corticosterone and thyroxine were administered in combination. These hormones were selected for several reasons. Somatotropin has induced a significant but limited increase in weight of the pancreas in hypophysectomized rats (Kinash et al., '53; Baker and Abrams, '55). The absolute weight of the parotid gland was increased, also, by somatotropin in hypophysectomized rats, although not out of proportion to the augmented body weight (Baker and Abrams, '55). Thyroxine was used be-

\footnotetext{
${ }^{1}$ Supported in part by research grants from the National Institutes of Health, United States Public Health Service A-131 (C5), American Cancer Society Institutional Research Grant \#35E, and from The Upjohn Company.
} 
cause the presence of thyroid hormone is essential for the full expression on general body growth of the growth-promoting action of crude pituitary preparations or purified somatotropin (Astwood, '55). Similarly, adrenalectomy impairs body growth, showing that adrenocortical steroids (Hartman and Thorn, '30) probably play a similar role. Corticosterone was selected because it is the major steroid secreted by the rat adrenal cortex.

\section{MATERIALS AND METHODS}

Young, adult, female Sprague-Dawley rats were hypophysectomized and subsequently kept in individual cages. For the first 15 days after the operation each non-hypophysectomized rat was fed each day the average amount of Purina Laboratory Chow consumed by the hypophysectomized rats on the previous day.

On the sixteenth day the rats in each experiment were divided into the following groups: (a) hypophysectomized, vehicle-treated, (b) hypophysectomized, hormone-treated, and (c) non-hypophysectomized, vehicle-treated. Somatotropin ${ }^{2}$ was dissolved in distilled water $(1.25 \mathrm{mg} / \mathrm{ml})$; corticosterone in $0.9 \% \mathrm{NaCl}(150 \mu \mathrm{g} / \mathrm{ml})$ with one drop of Tween 80 being added $10 \mathrm{ml}$ of saline as a suspending agent; and sodium lthyroxine pentahydrate was dissolved in distilled water (40 $\mu \mathrm{g} / \mathrm{ml}$ ) with one drop of $\mathrm{N} / 10 \mathrm{NaOH}$ per $50 \mathrm{ml}$ of solution being used to facilitate solution of the hormone. For treatment, $0.1 \mathrm{ml}$ of the somatotropin solution $(.125 \mathrm{mg}), 0.1 \mathrm{ml}$ of corticosterone $(15 \mu \mathrm{g})$ and $0.05 \mathrm{ml}$ of thyroxine $(2 \mu \mathrm{g})$ were drawn into a tuberculin syringe and administered together in one injection; the treatment was given twice daily, at 8:30 A.m. and 4:30 P.M. The non-hypophysectomized rats received an equal volume of $0.9 \% \mathrm{NaCl}$ with Tween 80 and N/10 $\mathrm{NaOH}$ being added in the amounts used for dissolving the

\footnotetext{
${ }^{2}$ We wish to express our appreciation to the Endocrinology Study Section, United States Public Health Service, for the somatotropin (Armour's Somar), to Merck and Company, Inc., for the corticosterone, and to Smith, Kline and Frencla Laboratories for the sodium l-thyroxine pentahydrate (Elthrin Sodium).
} 
hormones. Treatment was continued for 15 days with the animals being killed on the subsequent day.

Two experiments were carried out. In experiment I all rats were allowed to eat ad libitum beginning on the day that hormonal treatment was initiated. In experiment II the part played by increased food intake in facilitating the action of the hormones was studied with the daily food intake of each rat in the hypophysectomized, hormone-treated and non-hypophysectomized, vehicle-treated groups being limited daily to the average amount consumed by the hypophysectomized, vehicle-treated rats on the previous day. All rats were allowed free access to water but no food for 18-24 hours before termination of the experiment.

Organs were removed while the rats were under sodium amytal anesthesia. The stomach was dilated in situ with cold formalin-alcohol-acetic acid (FAA) and then immersed in this fluid for 48 hours. In a few eases Heidenhain's Susa was used. Salivary glands were fixed similarly. A portion of the pancreas was fixed in Bouin's fluid. Sections of the stomach wall and of the salivary glands were stained with periodic acid-leucofuchsin (PAS) and counterstained with either methylene blue in a citric acid-phosphate buffer ( $\mathrm{pH} 5.8$ ) or with $1 \%$ toluidine blue. Sections of pancreas were stained with Gomori's aldehyde fuchsin and counterstained by the Masson procedure.

In order to verify the completeness of hypophysectomy the pituitary area of all hypophysectomized, hormone-treated rats was sectioned and examined microscopically. Completeness of removal was proven in the hypophysectomized, vehicletreated rats by loss of body weight and failure to find pituitary tissue on gross examination of the pituitary area at necropsy. If there was any doubt concerning completeness of pituitary ablation, the area was sectioned and examined microscopically. All incompletely hypophysectomized rats were eliminated from consideration.

The Student-Fisher $t$ formula was used for statistical treatment of the data. P values of not greater than $5 \%$ were considered significant. 


\section{OBSERVATIONS}

Body weight. The mean body weight of hypophysectomized, vehicle-treated rats was less at the end than at the beginning of both experiments (table 1). The hypophysectomized rats injected with somatotropin, thyroxine and corticosterone (STC) exhibited a $22 \%$ gain in body weight if fed ad libitum

TABLE 1

Effect of STC on the mean weights of the body and pancreas

\begin{tabular}{|c|c|c|c|c|c|}
\hline \multirow{2}{*}{ TREATMLNT } & \multirow{2}{*}{$\begin{array}{c}\text { No. } \\
\text { OF } \\
\text { RATS }\end{array}$} & \multicolumn{2}{|c|}{ MODY WT. } & \multicolumn{2}{|c|}{ PANCREAS } \\
\hline & & Initial & Final & Gland & G.W./B.W. \\
\hline & & \multicolumn{2}{|c|}{$m m$} & \multicolumn{2}{|c|}{$m g$} \\
\hline \multicolumn{6}{|l|}{ Exp. I; ad lib. } \\
\hline Hyp.; veh. & 8 & $165 \pm 2^{1}$ & $142 \pm 3$ & $377 \pm 23$ & $2.6 \pm 0.2$ \\
\hline IHyp.; STC & 7 & $168 \pm 4$ & $205 \pm 6$ & $842 \pm 62$ & $4.2 \pm 0.3$ \\
\hline \multirow[t]{3}{*}{ Non-hyp.; veh. } & 8 & $173 \pm 3$ & $216 \pm 4$ & $885 \pm 67$ & $4.1 \pm 0.3$ \\
\hline & \multicolumn{3}{|c|}{ Groups 1 vs. 2} & $\mathrm{P}<0.001$ & $<0.001$ \\
\hline & \multicolumn{3}{|c|}{ Groups 2 vs. 3} & $\mathrm{P}>0.05$ & $>0.05$ \\
\hline \multicolumn{6}{|l|}{ Exp. II; pair-fed } \\
\hline Hyp.; veh. & 10 & $159 \pm 1$ & $150 \pm 3$ & $345 \pm 29$ & $2.3 \pm 0.2$ \\
\hline Hyр.; STC & 9 & $159 \pm 2$ & 178 上 3 & $695 \pm 30$ & $3.9 \pm 0.2$ \\
\hline \multirow[t]{3}{*}{ Non-hyp.; veh. } & 10 & $159 \pm 2$ & $188 \pm 3$ & $988 \pm 46$ & $5.3 \pm 0.3$ \\
\hline & & \multicolumn{2}{|c|}{ Groups 1 vs. 2} & $\mathrm{P}<0.001$ & $<0.001$ \\
\hline & & \multicolumn{2}{|c|}{ Groups 2 vs. 3} & $\mathbf{P}<0.001$ & $<0.001$ \\
\hline
\end{tabular}

Hyp. = hypophysectomized.

veh. = vehicle.

$\mathrm{STC}=$ somatotropin, thyroxine and corticosterone.

G.W./B.W. = gland weight (ng)/body weight (gm).

Standard error of the mean.

(experiment 1) and a $12 \%$ gain if their food intake was restricted to that of the hypophysectomized, vehicle-treated rats (experiment 2). The gain for the non-hypophysectomized, vehicle-treated rats in these experiments was 25 and $18 \%$, respectively. Thus, restriction of food intake to that of the hypophysectomized, vehicle-treated rats retarded the expected gain in weight of the hypophysectomized animals treated with STC. 
Pancreas. With ad libitum feeding STC increased the mean weight of the pancreas from $377 \mathrm{mg}$ to $842 \mathrm{mg}$ (table 1 , experiment 1 ). The latter weight was not significantly different from the mean of $885 \mathrm{mg}$ for the non-hypophysectomized rats. The gland weight/body weight (G.W./B.W.) ratios were practically identical. Thus, STC elicited practically complete restoration of the pancreas when judged solely on the basis of its weight. However, when the food intake of the STCtreated rats was restricted to that of their hypophysectomized, vehicle-treated controls, the therapy was less effective. Although the absolute weight of the pancreas and the G.W./B.W. ratios were increased significantly (table 1 , experiment 2), they did not reach the level shown by the pancreas of the non-hypophysectomized rats. The differences in absolute weight of the pancreas and in the G.W./B.W. ratios between the hypophysectomized, STC-treated and non-hypophysectomized, vehicle-treated rats were significant at the $0.1 \%$ level. Thus, STC can restore the weight of the pancreas in hypophysectomized rats to normal, providing free access to food is permitted.

As compared with non-hypophysectomized rats, the acinar cells of hypophysectomized rats were much reduced in size, and depleted of zymogenic granules and basal ergastoplasm (figs. 1 and 2). Nuclei were somewhat smaller. With ad libitum feeding, a striking restoration of these characteristics toward normal occurred in all hypophysectomized rats treated with STC. Especially significant were enlargement of the basal portion of the cell and increase in the amount of ergastoplasm. Although in many cases the number of zymogenic granules was approximately that of the non-hypophysectomized rats, usually this level was not reached. Nuclei and some nucleoli were enlarged, many nuclei becoming larger than those in the non-hypophysectomized rats. It seemed probable that the therapy induced polyploidy. If food intake was restricted, the response was similar except that a limited increase occurred in the number of zymogenic granules (fig. 3). 
Parotid gland. Treatment with STC caused a marked elevation in weight of the parotid gland which with pair-feeding gave absolute weights and G.W./B.W. ratios in the hypophysectomized, hormone-treated group which were identical with those of the non-hypophysectomized, vehicle-treated group (table 2, experiment 2). With ad libitum feeding both of these values were less for the hypophysectomized, hormone-treated group than for the non-hypophysectomized, vehicle-treated animals although the differences between them were not significant at the $5 \%$ level.

The major cytological change observed in the parotid gland after hypophysectomy was reduction in size of epithelial cells with depletion of zymogenic granules (figs. 4 and 5). The degree of restoration in these parameters following STC therapy of hypophysectomized rats varied from animal to animal and among different acini within a single gland. In 2 of 7 rats of experiment 1 and in 7 of 9 treated rats of experiment 2 the size and granulation of the acinar cells had returned to the state seen in the non-hypophysectomized rats (fig. 6). All of the remaining STC-treated rats showed variable degrees of improvement.

Submandibular gland. After treatment of hypophysectomized rats with STC, the absolute weight of the submandibular gland and the G.W./B.W. ratio were greater than in the rats which were hypophysectomized and given the vehicle (table 2). Nevertheless, these values for the hormone-treated rats were still significantly less than those for the nonhypophysectomized groups. The differences between these groups were affected little by the type of feeding.

After hypophysectomy the epithelium of the serous ducts and of the intercalated ducts was degranulated almost completely, with a marked reduction in size of the cells. The acini were somewhat smaller and stained less intensely with PAS. Treatment with STC induced only a slight restoration of the granules in the serous tubules, no significant change in the intercalated ducts, a mild enlargement of the acini and increase in the intensity of the PAS reaction. Thus, the hor- 
mones failed to effect complete recovery of submandibular structure.

Gastric chief cells. Following hypophysectomy, gastric chief cells were small and depleted of pepsinogen granules and cytoplasmic ribonucleic acid, the latter being revealed by reduced basophilia (figs. 7 and 8 ). In experiment 2,6 of the 9 hypophysectomized rats which received STC showed

TABLE 2

Effect of STC on the mean weights of submandibular and parotid glands

\begin{tabular}{|c|c|c|c|c|}
\hline \multirow{2}{*}{ 'TREATMENT } & \multicolumn{2}{|c|}{ SUBMANDIBULAR } & \multicolumn{2}{|c|}{ PAROTID } \\
\hline & Gland & G.W./B.W. & Gland & a.W./B.w. \\
\hline & \multicolumn{2}{|c|}{$m g$} & \multicolumn{2}{|c|}{$m g$} \\
\hline$E x p . I ; a d l i b$. & & & & \\
\hline Hyp.; veh. & $93 \pm 4^{1}$ & $0.66 \pm 0.03$ & $77 \pm 7$ & $0.54 \pm 0.05$ \\
\hline Hyp.; STC & $159 \pm 6$ & $0.78 \pm 0.04$ & $158 \pm 13$ & $0.78 \pm 0.06$ \\
\hline Non-hyp.; veh. & $191 \pm 5$ & $0.86 \pm 0.02$ & $188 \pm 15$ & $0.86 \pm 0.07$ \\
\hline Groups 1 vs. 2 & $\mathrm{P}<0.001$ & $<0.05$ & $<0.001$ & $<0.01$ \\
\hline Groups 2 vs. 3 & $\mathrm{P}>0.05$ & $>0.05$ & $>0.05$ & $>0.05$ \\
\hline \multicolumn{5}{|l|}{ Exp.II; pair-fed } \\
\hline Hур.; veh. & $100 \pm 6$ & $0.67 \pm 0.04$ & $95 \pm 10$ & $0.63 \pm 0.07$ \\
\hline Hyp.; STC & $143 \pm 6$ & $0.81 \pm 0.03$ & $176 \pm 11$ & $0.99 \pm 0.06$ \\
\hline Non-hyp.; veh. & $180 \pm 5$ & $0.96 \pm 0.02$ & $177 \pm 16$ & $0.99 \pm 0.08$ \\
\hline Groups 1 vs. 2 & $\mathrm{P}<0.001$ & $<0.05$ & $<0.001$ & $<0.02$ \\
\hline Groups 2 vs. 3 & $\mathrm{P}<0.001$ & $<0.001$ & & \\
\hline
\end{tabular}

Hyp. = hypophysectomized.

veh. = vehicle.

$\mathrm{STC}=$ somatotropin, thyroxine and corticosterone.

G.W./B.W. = gland weight $(\mathrm{mg}) /$ body weight $(\mathrm{gm})$.

${ }^{\mathcal{S}}$ Standard error of the mean.

definite cellular enlargement and partial regranulation, the latter change being revealed by an increase in apical vacuolation since fixation in FAA did not preserve zymogenic granules in these cells (fig. 9). In these cases, cytoplasmic basophilia, which is due to the presence of ribonucleic acid, was also increased in intensity. However, in none of these 6 animals were the chief cells brought back to the structure observed in non-hypophysectomized rats. A similar degree of recovery was induced by STC in experiment 1 . 


\section{DISCUSSION}

Pancreas. The results reported herein represent the most successful restoration of pancreatic weight in hypophysectomized rats yet observed following the administration of purified or pure hormones. Utilization of several different types of growth hormone preparations by Kinash et al. ('53) and Baker and Abrams ('55) effected a significant increase in weight of the pancreas. However, the pancreas was not restored completely and the former investigators concluded that " . . . some further factor not present in the growth hormone preparations appears to be required." Treatment with cortisone also has been found to increase pancreatic weight in hypophysectomized rats (Kinash and Haist, '54; Baker and Abrams, '55) even though loss of body weight occurred at the same time. Again normal values were not attained. Although much evidence indicates that the thyroid gland influences the histology and function of the exocrine portion of the pancreas (Bicknell and Baker, unpublished), there are no reports of complete restoration of pancreatic weight in hypophysectomized rats by the administration of thyroid substance. Our numerous attempts to accomplish this by the injection of low doses of thyroxine have failed. Feeding of desiccated thyroid in doses sufficiently large to reduce the body weight of hypophysectomized rats elicited a striking increase in weight of the pancreas (Kinash and Haist, '55).

Comparison of the results obtained in the two experiments shows clearly the importance of food intake in facilitating the action of hormones on the pancreas, since restriction of food intake to the low level of non-treated hypophysectomized rats prevented full restoration in weight of the pancreas. The eapacity of the gland to develop its normal store of zymogenic granules also is partially dependent on food intake since in the STC-treated, hypophysectomized animals fed ad libitum the number of granules was more nearly normal than in those whose food intake was restricted. Two important inferences may be drawn from these observations. First, the profound atrophy which typifies the pancreas of 
hypophysectomized animals is due in part to their reduced appetite. Second, since zymogenic granules represent stored enzymes or their precursors, in order to effect an approximately normal level of enzyme synthesis and storage by treatment of hypophysectomized rats with STC, voluntary eating must be allowed.

Parotid gland. Implantation of pituitary glands into hypophysectomized rats profoundly stimulated the parotid gland (Baker and Pliske, '57). Treatment with somatotropin alone for 7 days increased the absolute weight of the gland but not out of proportion to the increase in body weight (Baker and Abrams, '55). Clarification of the pituitary-parotid gland relationship is important because of the postulation that secretion of the hormone, parotin, by the parotid gland mediates the action of pituitary growth hormone (Ito, '54). A significant role for somatotropin in maintaining the parotid gland is indicated by the capacity of STC to restore to normal parotid weight in hypophysectomized rats in spite of limitation in food intake. We cannot explain why the therapy was less sucessful in increasing weight of the gland when free access to food was permitted.

Submandibular gland. The incapacity of STC to bring the submandibular gland back to normal was expected, since Grad and Leblond ('49) have demonstrated the important role of testosterone in maintenance of the serous ducts. Atrophy of these ducts accounts primarily for the loss in weight of the gland after hypophysectomy.

Gastric chief cells. In contrast to the significant repair effected by STC in the pancreas and parotid gland, the limited and variable success achieved with gastric chief cells suggests that other unknown factors exist which are necessary in order to maintain the normal structure and activity of these cells. Because of this observation and previous failure to effect complete restoration with somatotropin alone (Baker and Abrams, '55), the report by Kyle and Welbourn ('56) that administration of somatotropin, corticotropin or cortisone will restore to normal the volume and $\mathrm{pH}$ of gastric juice in hypophysec- 
tomized rats, should not be interpreted to mean that the gastric mucosa of their rats was completely normal.

The recent successful repair of the atrophic bone marrow and correction of the anemia of hypophysectomized rats (Meineke and Crafts, '57) by treatment with growth hormone, thyroxine and cortisone, suggests that erythropoiesis and maintenance of pancreatic and parotid histology require a similar hormonal support.

\section{SUMMARY}

Following hypophysectomy, zymogenic cells undergo partial involution. In the present experiments restoration was attempted in hypophysectomized rats by treatment with somatotropin, thyroxine and corticosterone, the hormones being mixed before administration and injected into a single site. In one experiment all rats were allowed to eat ad libitum; in another, food intake was restricted to that of the hypophysectomized, vehicle-treated rats. Almost complete structural recovery was effected in the pancreas if food intake was not restricted. Complete recovery in weight and marked improvement in cytology of the parotid acini occurred in spite of food restriction. The epithelium of the serous tubules in the submandibular gland showed only a slight return toward normal. Many gastric chief cells were enlarged and contained more zymogenic granules and cytoplasmic ribonucleic acid than in hypophysectomized, vehicle-treated rats. However, the response was irregular and invariably did not reach the condition of the non-hypophysectomized rats. It was concluded that somatotropin plays a significant role in maintenance of the parotid gland and pancreas and that thyroid and adrenocortical hormones support its action on these glands.

\section{LITERATURE CITED}

Astwood, E. B. 1955 Growth hormone and corticotropin. In: The Hormones. Ed. by G. Pincus and K. V. Thimann. Acad. Press, Ine., New York, 3: $235-308$.

BAKER, B. L. 1957 The influence of the hypophysis and adrenals on digestive function. Am. J. Clin. Nutr., 5: 445-452. 
BAKER, B. I., AND G. D. ABRAMS 1954 Effect of hypophysectomy on the cytology of the fundic glands of the stomach and on the secretion of pepsin. Am. J. Physiol, 177: 409-412.

1955 Growth hormone (somatotropin) and the glands of the digestive system. In: The Hypophyseal Growth Hormone, Nature and Actions. Ed. by R. W. Smith, Jr., O. H. Gaebler and C. N. H. Long. The Blakiston Division, MeGraw-Hill Book Co., Inc., New York.

Baker, B. L., J. F. KENT AND E. C. Pliske Histological response of the duodenum to $\mathrm{X}$-irradiation in hypophysectomized rats. Rad. Res., in press.

BAKER, B. L., AND E. C. Phiske 1957 Endocrine regulation of zymogenic celis. In: The Biological Action of Growth Substances. Sym. Soc. Exp. Biol., no. XI, 329-344.

GRAD, B., AND C. P. LEBloND 1949 The necessity of testis and thyroid hormones for the maintenanee of the serous tubules of the submaxillary gland in the male rat. Endocrinol., 45: 250-266.

Hartman, F. A., AND G. W. Thorn 1930 A biological method for the assay of cortin. Proe. Soc. Exp. Biol. and Med., 98: 94-95.

Iто, Y. 1954 Biochemical studies on salivary gland hormone. Endocrinologia Jap., 1 : 1-50.

KINASH, B., AND R. E. HAIST 1954 Effect of ACTH and of cortisone on the islets of Langerhans and the panereas in intact and hypophysectomized rats. Am. J. Physiol., 178: 441-444.

1955 The influence of the thyroid gland on the islets of Langerhans and the pancreas. Canad. J. Biochem., 33: 380-384.

Kinash, B., I. MacDougall, M. A. Evans, F. E. Bryans and R. E. Haist 1953 Effects of anterior pituitary extracts and of growth hormone preparations on the islets of Langerhans and the pancreas. Diabetes, 2 : 112-121.

KYLE, J., AND R. B. WelbourN 1956 The influence of the adenohypophysis and the adrenal cortex on gastric secretion in the rat. Brit. J. Surg., 44: 241-247.

Lacassagne, A., And A. Chamorro 1940 Réaction a la testostérone de la glande sous-maxillaire, atrophiée consécutivement a l'hypophysectomie chez la souris. Compt. Rend. Soc. de Biol., 134: 223-227.

MeINEKe, H. A., AND R. C. CRAFis 1957 Effect of combined thyroxine-cortisonegrowth hormone therapy on hematopoiesis in hypophysectomized rats. Proc. Soc. Exp. Biol. and Med., 96: 74-79.

Yoshimura, F. 1956 Cytological changes in rat salivary glands following hypophysectomy and somatrophic hormone administration. Okajimas Folia Anat. Jap., 28: 195-205. 
PLATE 1

EXPLANATION OF FIGURES

The specimens for figures 1-3 were fixed in Bouin's fluid and stained with Gomori's aldehyde fuchsin and the Masson procedure; those for figures 4-6 were fixed in FAA and stained with PAS and methylene blue, and those for figures 7-9 were fixed in FAA and stained with PAS and toluidine blue. $\times 670$. All specimens are from pair-fed animals (experiment 2).

1 Pancreas from a non-hypophysectomized rat. Acinar cells are filled with zymogenic granules and have extensive basal ergastoplasm.

2 Pancreas from a hypophysectomized, vehicle-treated rat. Compared with figure 1, the acini are small and depleted of granules and ergastoplasm.

3 Panereas from a hypophysectomized, STC-treated rat. The size of epithelial cells approximates normal, granules are increased over the number in figure 2, and much of the ergastoplasm is restored. Some nuclei (arrow) are greatly enlarged.

4 Parotid gland from a non-liypophysectomized rat. In the acinar epithelium, basophilia is distributed diffusely between zymogenic granules which are stained faintly with PAS. Some zymogenic granules were not fixed, leaving vacuoles in the cytoplasm. The epithelium of the centrally located intercalated duct contains granules (black) stained with PAS. 


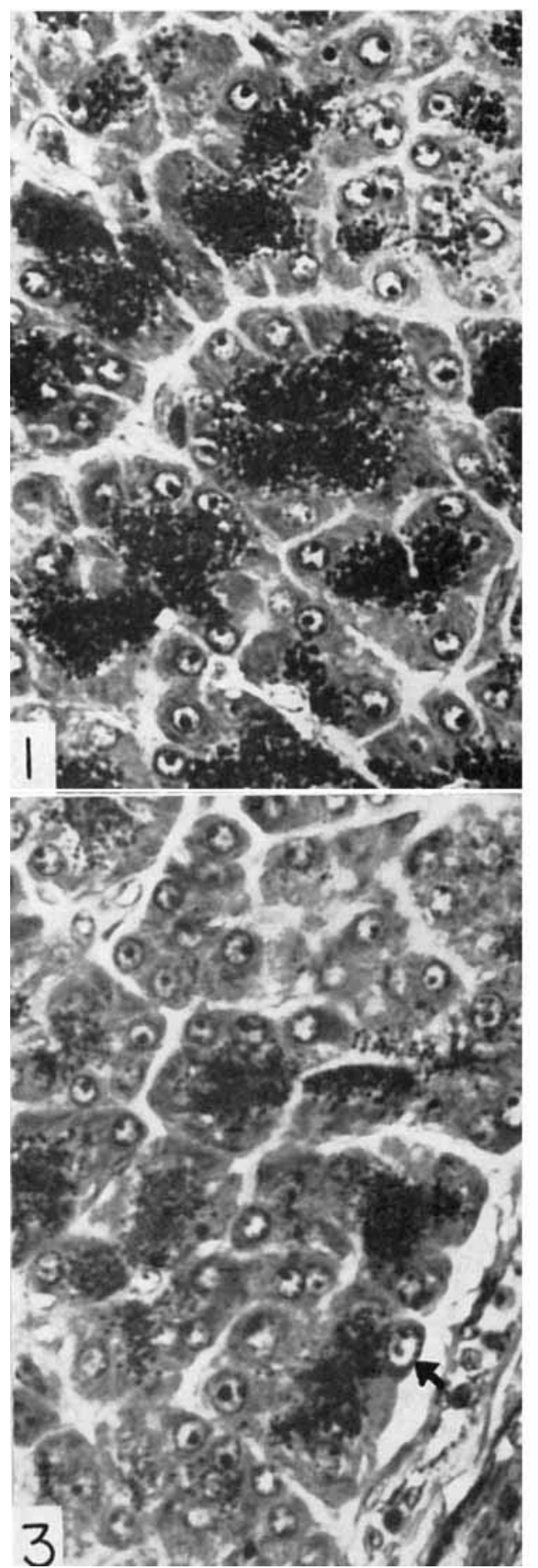

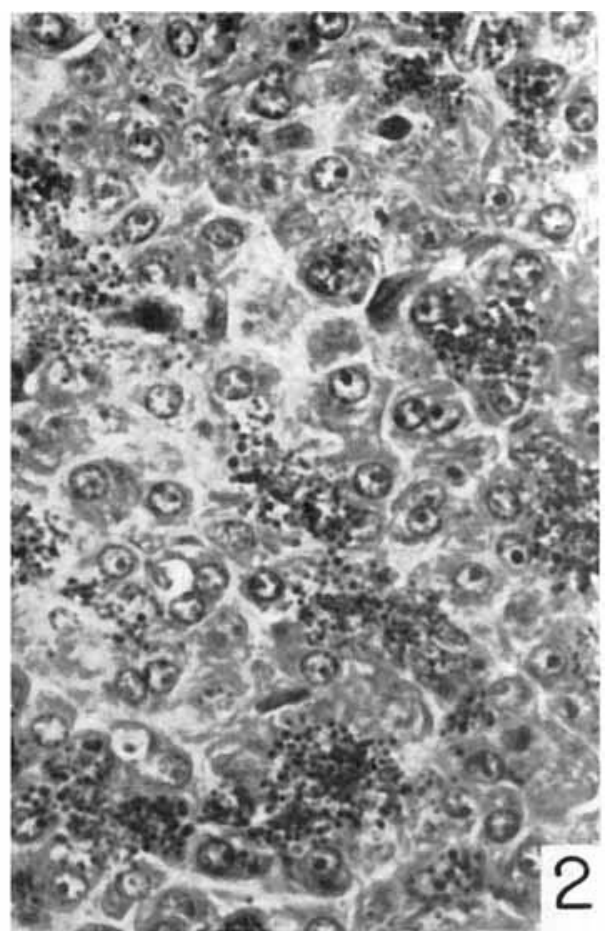

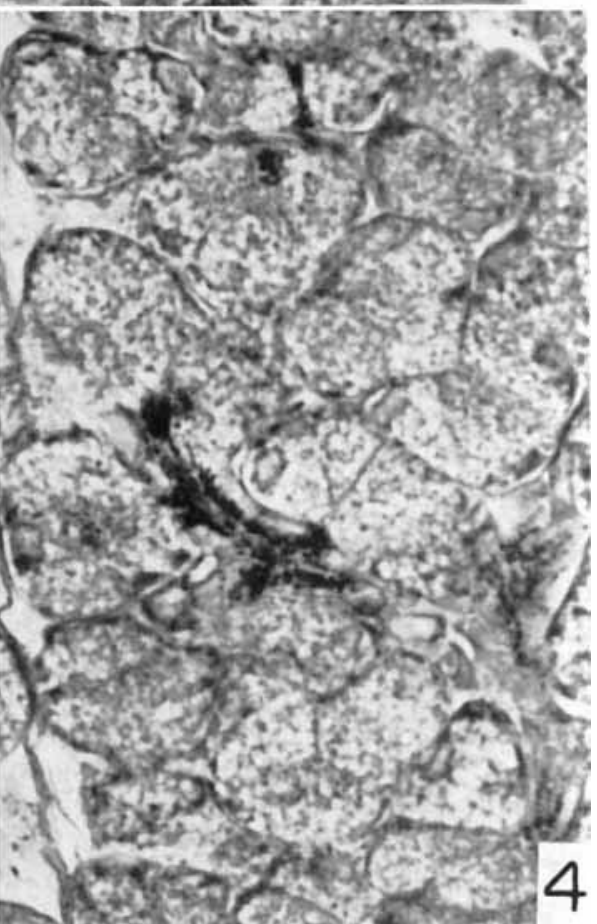




\section{PISATE: 2}

EXPLANATION OF MIGURFS

j Parotil gland from a lypophysectomized, veliele-treated rat. Compared with figure 4, acinar epithelial cells are smaller and partially depleted of zymogenic granules.

6 Parotid glaul from a bypoplyysectomized, STC-treated rat. Acinar eclls closely resemble those of figure 4.

7 Glandular stomach from a non-hypophysectomized rat. Pepsinogen granules in the chief cells are not preserved by the fixative but their number and size are indicated by the apical vacuoles. There is intense basal hasophilia.

8 Glandular stomach from a hypophysectomized, vehiele-treated rat. Chief cells are reduced in size and have fewer apieal vacuoles and less basophilia.

9 Glandular stomach from a liypophysectomized, 8TC-treated rat. As rompared with those in figure 8, the elief cells are enlarged, contain more apieal vacuoles and basal basophilia. However, they are not restored to the condition of those in figure 7 . 


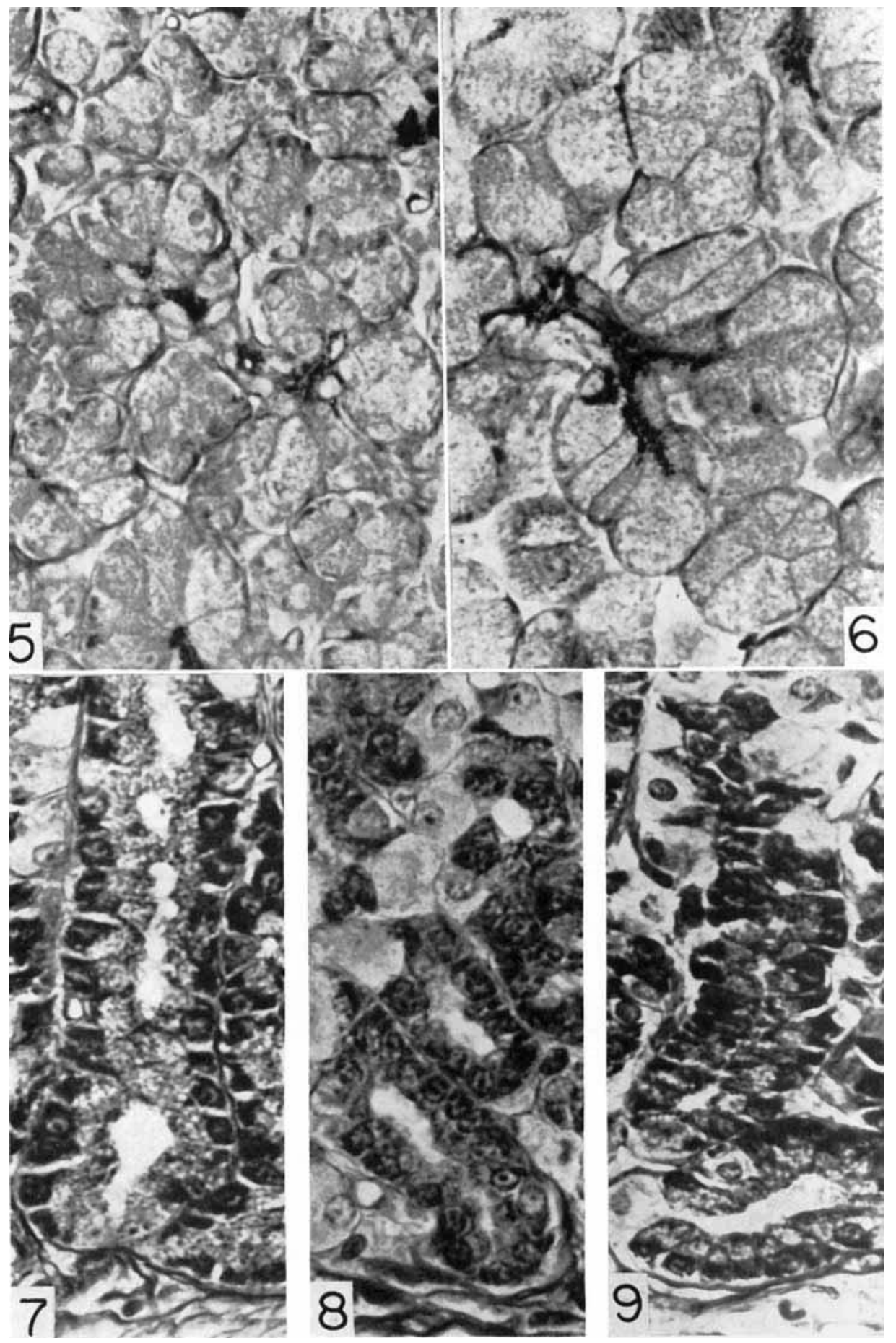

